جامعتما الموصل كليتالآثار

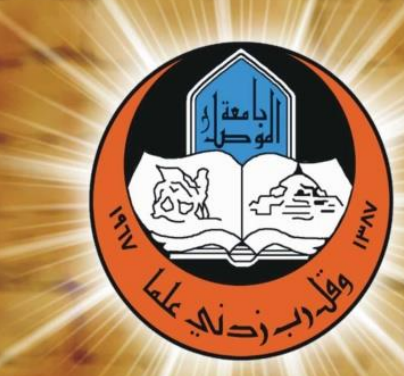

وزارة التعليم العالي

$$
\text { والبحث العلمي }
$$

ISSN $2304-103 X$ (Print)

ISSN 2664-2794(Online)

$\| \vec{R}=$

Academic Scientific Journals

(4)

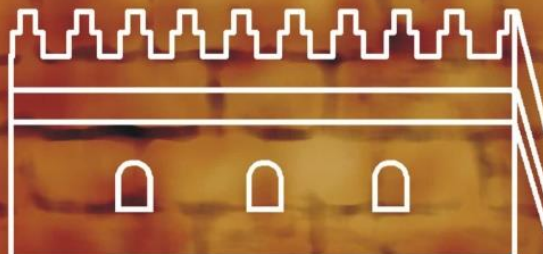

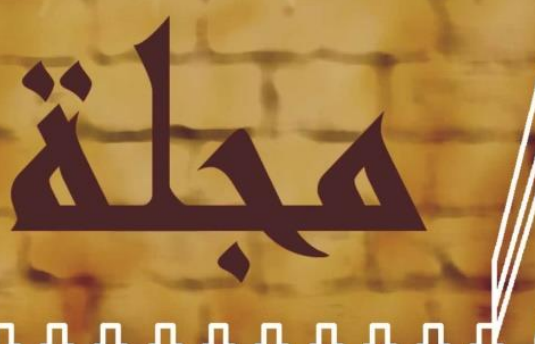

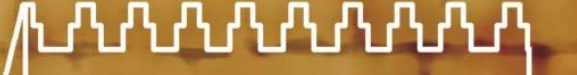

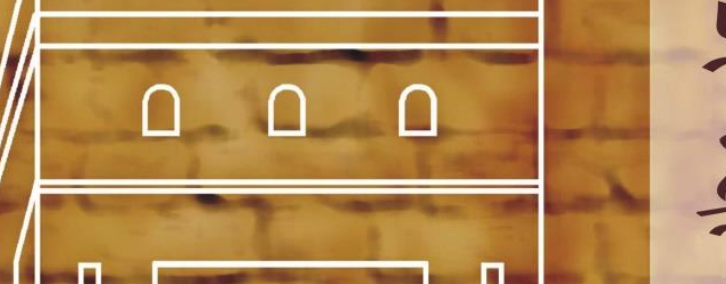

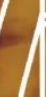

$>$

N का च्छ

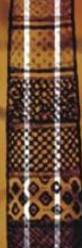

گل

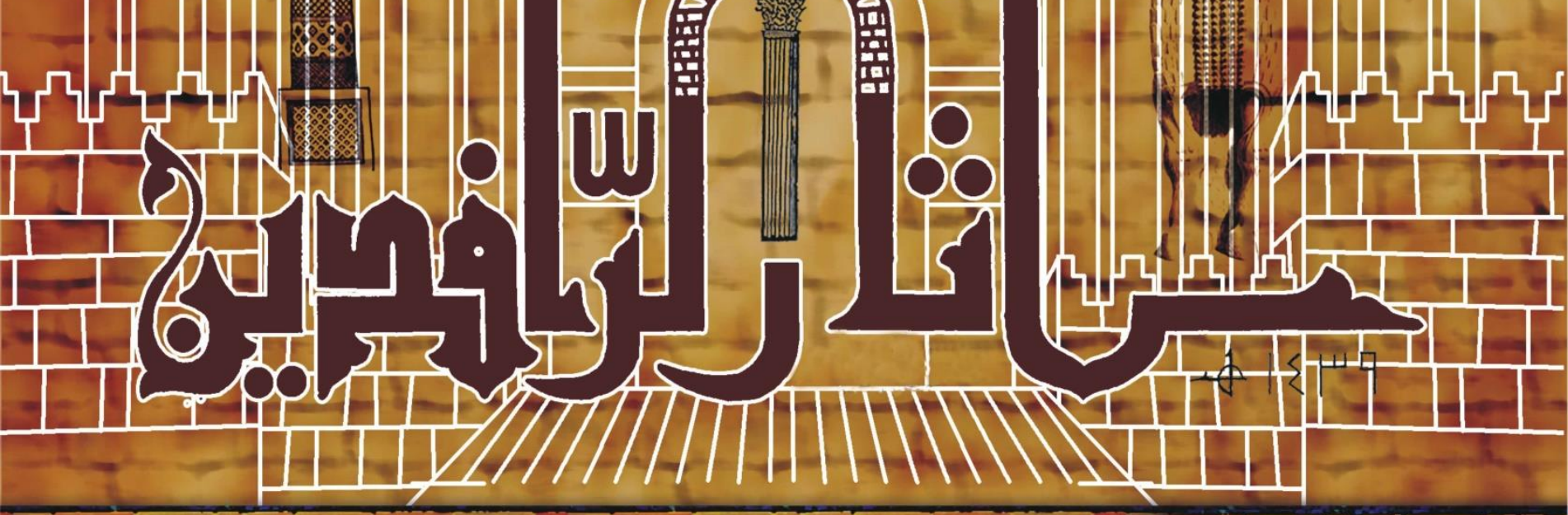

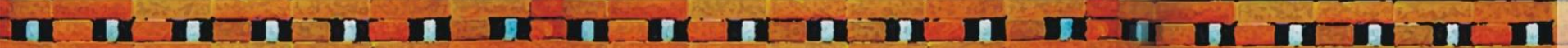

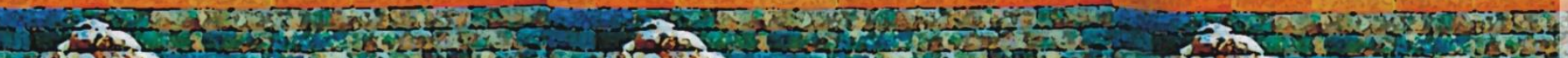

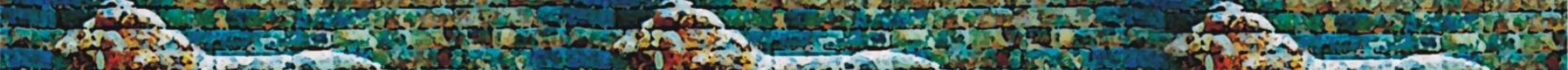
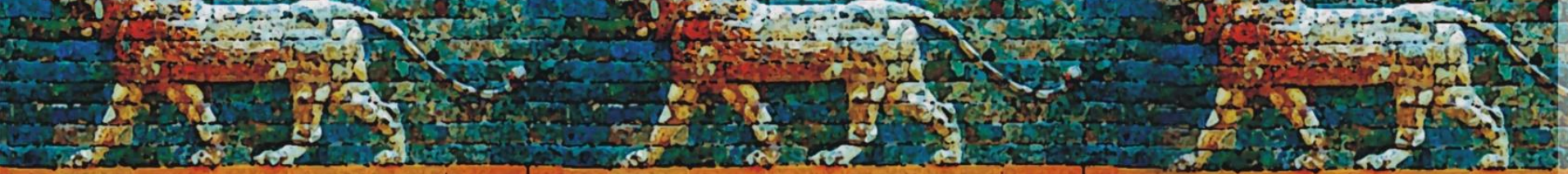

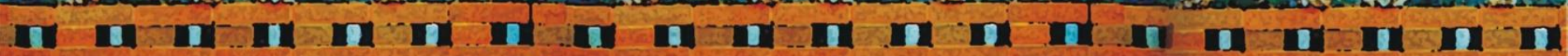

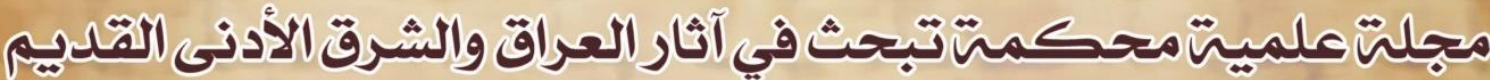

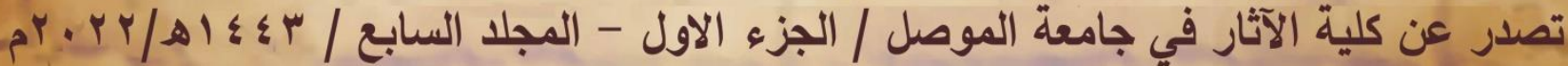




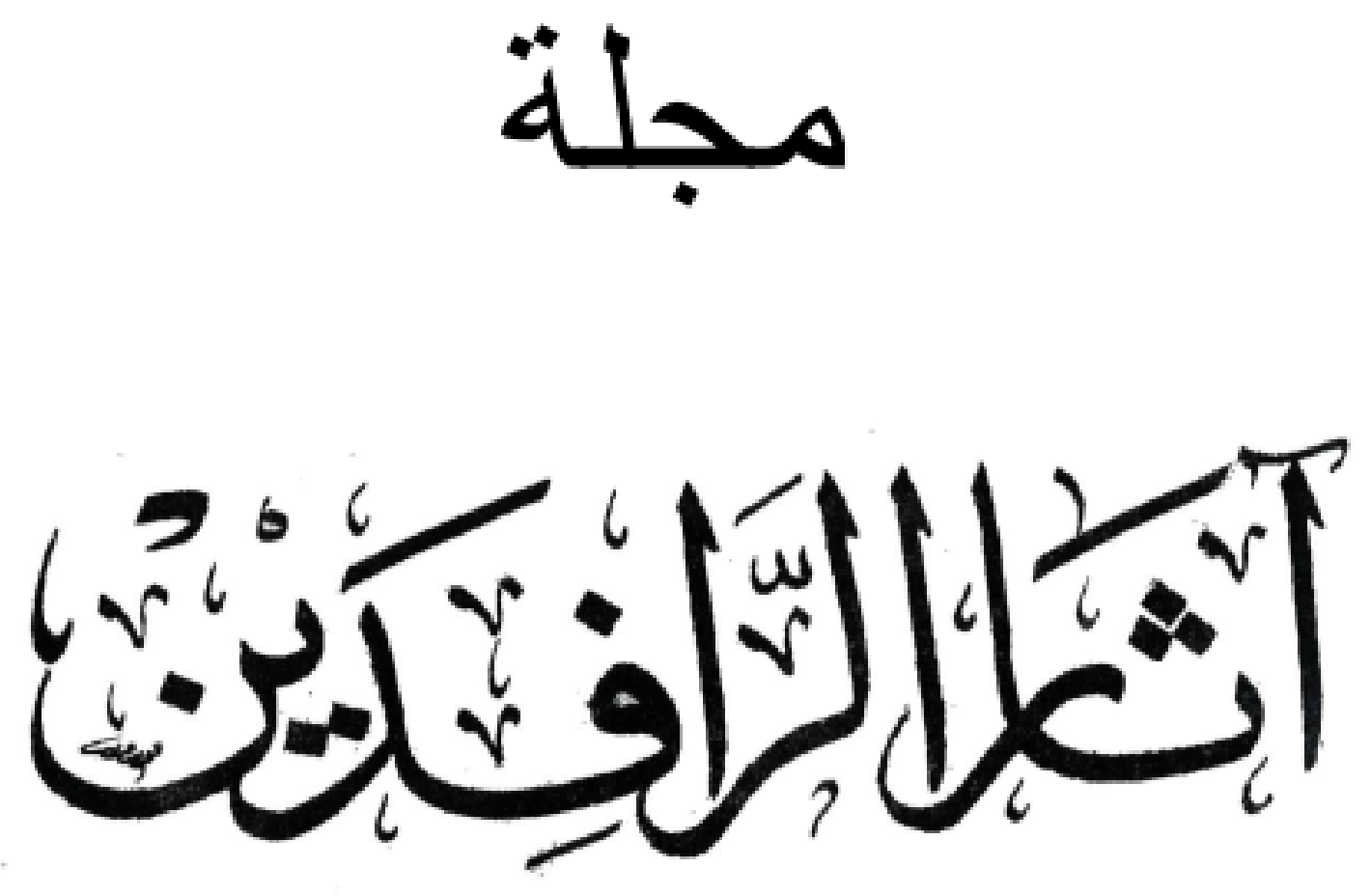

هبلة علمية هحكمة تبحث في آثار العراق و الشرق الأدنى القديم تصدر عن كلية الآثار في جاهعة الموصل

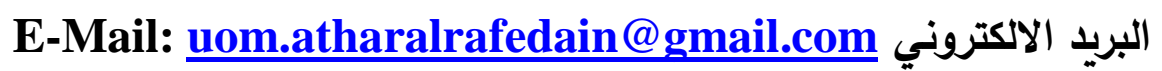

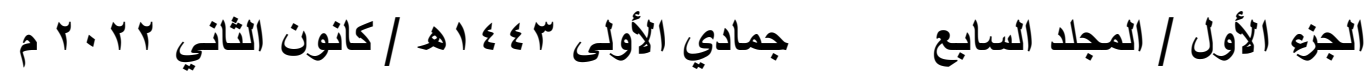

$$
\begin{aligned}
& \text { رقم الايداع في دار الكتب والوثائق ببغداد الاع }
\end{aligned}
$$

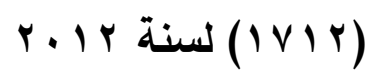





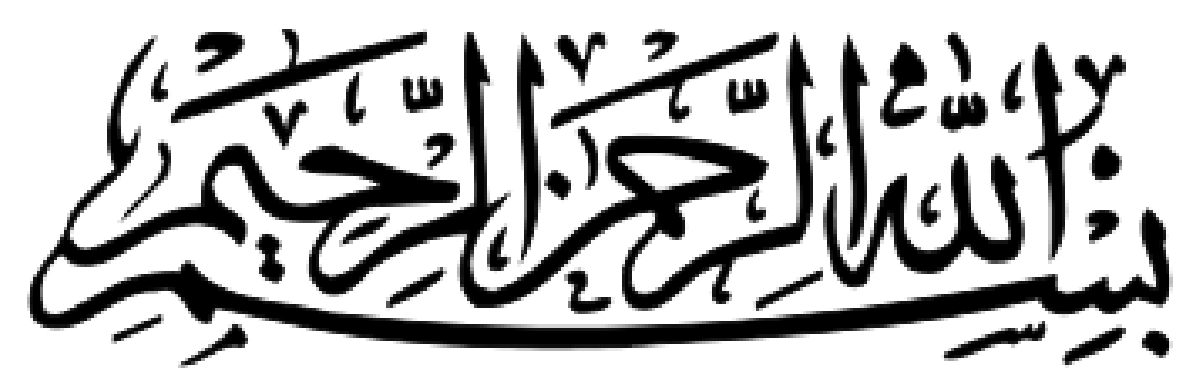



هيأة التمرير

أ. خالد سالم اسماعيل

رئيس التحريز

أ.م. هسنين حيدر عبد الواحد

الاعضاء

أ.د. اليزابيث ستون

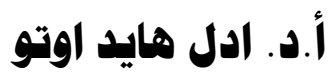

أ.د. والتز سلابيركر التر

أ.د. نيكولو هاركيتي

أ.د. هديب حياوي عبد الكريم

أ.د. جهواد هطر الموسوي

أ.د. رفاه جاسم حمادي

أ.د. عادل هاشم علي

أ.م.د. ياسمين عبد الكريم هممد علي

أ.م.د. فيان هوفق رشيد

أ.م.د. هاني عبد الغني عبد الله 


$$
\begin{aligned}
& \text { هقوم اللغة العربية } \\
& \text { أ.م.د. همن يهيى همهد } \\
& \text { قسم اللغة العربية / كلية الآداب / جاهعة الموصل همد لمد }
\end{aligned}
$$

$$
\begin{aligned}
& \text { هقوم اللغة الانكيرية }
\end{aligned}
$$

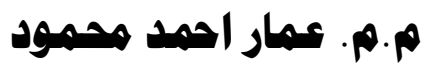

$$
\begin{aligned}
& \text { قسم الترجمة / كلية الآداب / جاهعة الموصل }
\end{aligned}
$$

$$
\begin{aligned}
& \text { تنضيد وتنسيق } \\
& \text { م.م. ثائر سلطان درويش }
\end{aligned}
$$

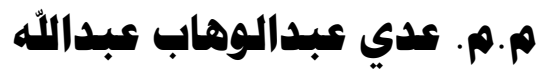

$$
\text { د. تصاهيم الغلاف }
$$




\section{قواعد النشر في مجلة آثار الرافدين}

$$
\begin{aligned}
& \text { 1- تقبل المجلة البحوث العلمية التي تقع في تخصصات: } \\
& \text { • • علم الاثار بفرعيه القديم والإسلامي • } \\
& \text { ه اللغات القديمة بلهجاتها و الدراسات الدقارنة. } \\
& \text { • الكتابات المسمارية و الخطوط القديمة . } \\
& \text { • الدراسات التاريخية والحضارية . }
\end{aligned}
$$

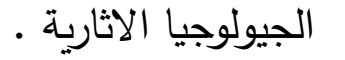

$$
\begin{aligned}
& \text { • تقنيات المسح الاثاري • }
\end{aligned}
$$

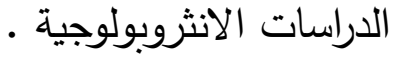

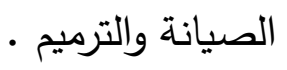

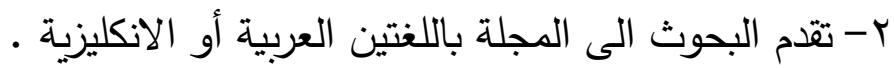

r-يطبع البحث على ورق (A4)، وبنظام (2010 - word)، وبمسافات مزدوجة بين الاسطر ، وبخط Simplified Arabic للغة العربية، و Times New Roman للغة

$$
\text { الانكليزية، ويسلم على قرص ليزري (CD) ، وبنسختين ورقيتين. }
$$

ع- يطبع عنوان البحث في وسط الصفحة يليه اسم الباحث ودرجته العلمية ومكان عمله

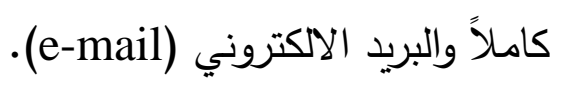

0- يجب ان يحتوي البحث ملخصا باللغتين العربية والانكليزية على ان لا تزيد عن (. ( )

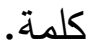

צ- يحتوي ملخص البحث بالإنكليزية على عنوان البحث واسم الباحث ودرجته العلمية ومكان عمله كاملاً والبريد الالكتروني له. V- Vضمين البحث كلمات مفتاحية تتعلق بعنوان البحث ومضمونه. ^- ان لا يكون البحث قد تم نشره سابقا أو كان مقدما لنيل درجة علمية أو مستلاً من ملكية

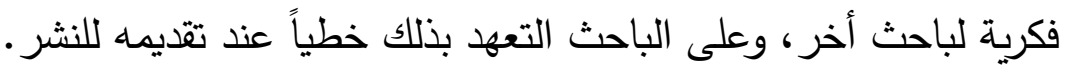
9- يلتزم الباحث باتباع الاسس العلمية السليمة في بحثه. • (- يلزم الباحث بتعديل فقرات بحثه ليتناسب مع مقترحات الخبراء واسلوب النشر في 
11-لا تتجاوز عدد صفحات البحث عن (ro)، صفحة وفي حال تجاوز العدد المطلوب يتكفل الباحث بدفع مبلغاً اضافياً عن كل صفحة اضافية.

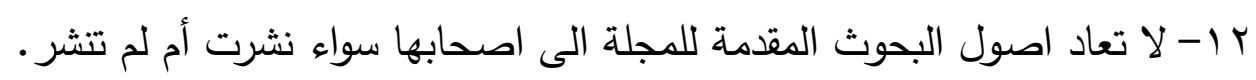
با ا-ترقم الجداول والاشكال على التوالي وبحسب ورودها في البحث، وتزود بعناوين، وتقدم بأوراق منفصلة وتقدم المخططات بالحبر الاسود والصور تكون عالية الدقة. ع ا-تكتب ارقام الهوامش بين قوسين وترد متسلسلة في نهاية البحث.

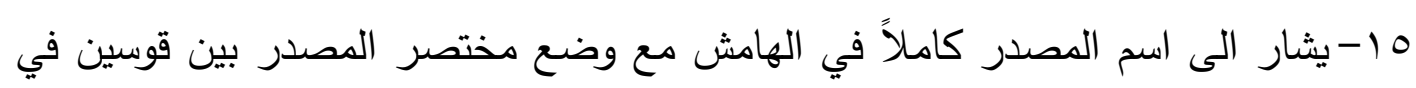
نهاية الهامش.

77 - 17 V V Vعمل المجلة وفق التمويل الذاتي، ولذلك يتحمل الباحث اجور النشر البالغة

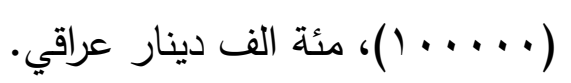

11 إيزود كل باحث بمستل من بحثه، أما نسخة المجلة كاملة فتطلب من سكرتارية المجلة لقاء ثمن تحدده هيأة التحرير • 9 1 - ترسل البحوث على البريد الالكتروني للمجلة: uom.atharalrafedain@gmail.com 


\section{ثبت المحتويات}

\begin{tabular}{|c|c|c|}
\hline 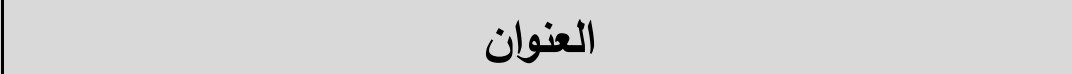 & 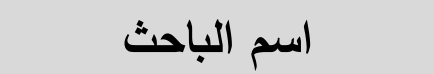 & الصفحة \\
\hline توطئة & خالد سالم اسماعيل & 1 \\
\hline النخلة عند اليونان والرومان & واثق اسماعيل الصالحي & r-r \\
\hline الاسكندر المقدوني والطريق الى كوكاميلا & جابر خلير زهير خضر ابراهيم & $07-Y_{0}$ \\
\hline دراسة للرأس البرونزي الأكدي المكتشف في نينوى & حسين ظاهر حمود & $V \wedge-O V$ \\
\hline تطور مدينة التون كوبري (بردىّ) في ضوء البحوث الآثارية والتاريخية & نرمين محمد علي & $90-V 9$ \\
\hline الوشم من مظاهر التراث الرافديني القديم & طورهان مظهر المفتي منديل & $14 q-q V$ \\
\hline القبة الرافدينية "قبة بخديدا انموذجا" & 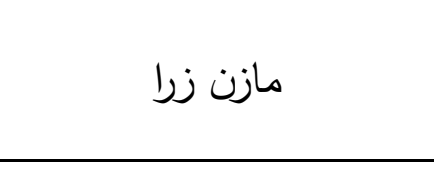 & $|7 \varepsilon-| 11$ \\
\hline نصوص أكدية غير منشورة في المتحف العراقي & 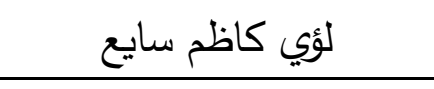 & $1 \wedge \varepsilon-170$ \\
\hline مخطوطة: المغنية في اختصار كتاب التوطئة لنحو اللغة السامرية - & هاشم طه رحيم الزبيدي & $r \cdot \varepsilon-110$ \\
\hline زخارف الحرف اليدوية (الارابسك) - الماضي والحاضر والمستقبل - سوريا أنموذجاً & منذر عبد المنعم حمد يونس الطائي & $r r \Lambda-r .0$ \\
\hline \multicolumn{3}{|c|}{ القسم الانكليزي: } \\
\hline نصان مسماريان من مدينة أيري - ساكرك يتضمنان صيغاً أكدية & خالد سالم اسماعيل حمد احمد & 10-r \\
\hline
\end{tabular}



مجلة آثار الرافدين / ج / / مجلة V / Y r r T 
- Hilgert, 2002 Hilgert, M., Akkadisch in Der Ur III-Zeit, Munster, 2002.

- Ismael, 2020 Ismael, K.S., Khorsheed, O.M., Akkadian Formulas in a New Cuneiform Texts from Ur III period Kept in the Iraqi Museum, Journal Athar Al-Rafedain, vol.5/2, Mosul, 2020.

- Owen, 2013 Owen. D.I., et al., Cuneiform Texts primarily from Irisaĝrig / Al-šarrāki and the History of the Ur III Period. vol. 2: Catalogue and Texts, Bethesda, 2013.

- Owen, 2019 Owen, D.I., " Death for Default " Redux. Akkadian Field Cultivation and other Akkadian Contracts from Iri-Saĝrig, DE L'argile Au Numéroique, PIPOAC. 3, Paris, 2019.

- Sigarist, 2019 Sigarist, M., Ozaki, T., Tablets from the Iri-Saĝrig Archive, it Munster, 2002, p.730; p.740.

- CUSAS, 40/1 \& 2, Pennsylvania, 2019. 


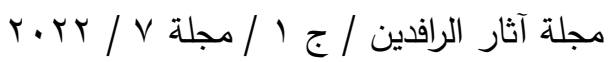

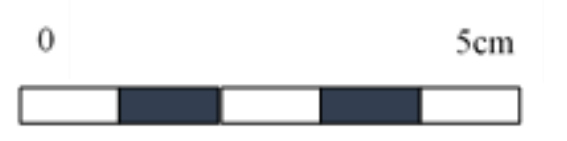

\section{References:}

1- Ismael, K.S.; Khorsheed, O.M., Journal Athar Al-Rafedain, vol. 5/2, 2020, pp.7-16.

2- Sigarist, M., Ozaki, T., CUSAS, 40/1 \&2 No. 166; No. 436; No. 1788.

3- Owen, D.I., " Death for Default " Redux. Akkadian Field Cultivation and other Akkadian Contracts from Iri-Saĝrig,

Paris,2019,Nos.42,243,247,436,614,751, 1449,1453,1551,1788,1849 and IM.235545.

4- Ismael and Khorsheed, op.cit, p.7.

5- Ismael and Khorsheed, op.cit, p.10.

6- Charpin, D., OBO, 60/4, 2004, p.385.

7- Sigarist and Ozaki, 40/1, p.37: No. 166.

8- CAD, E, p. 238.

9- CDA, p. 245: a cf. našappu(m).

10-Ismael and Khorsheed, op.cit, pp. 10:13.

11-Owen, D., Akkadian field ..., p. 780; p. 783.

12-Hilgert, M., Akkadisch in Der Ur III-Ze

\section{Bibliography:}

- Charpin, D. \& Eszard, D.O. \& Stole, M., Mesopotamien Die altbabylonische Zeit, OBO, 60/4,Fribourg, 2004. 
خلي محمد احمد

نصان مسماريان جديدان من مدينة أيري - ساكرك يتضمنان صيغاً أكدية

\section{2. (IM. 235558)}

Obv.
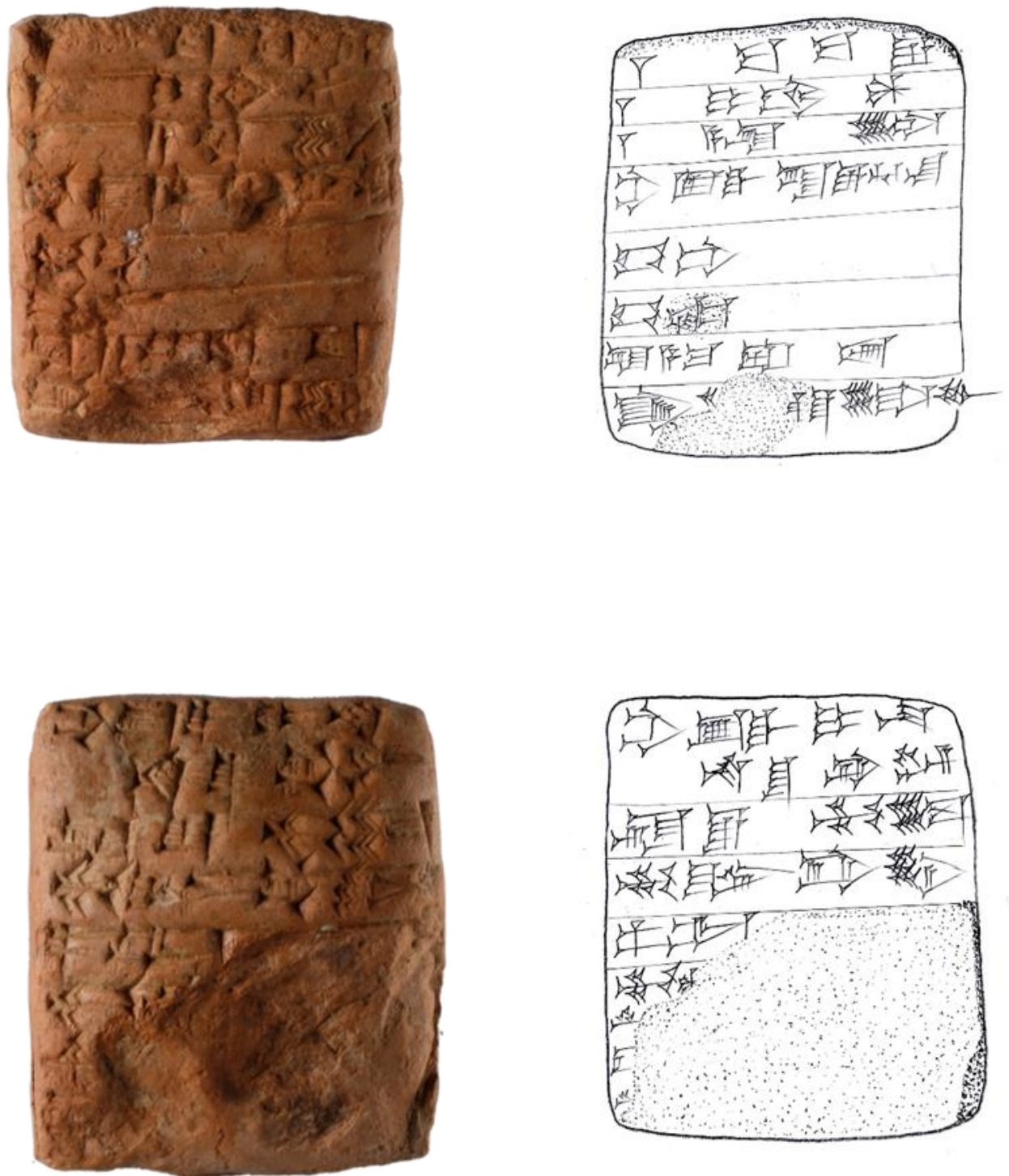

Rev. 
مجلة آثار الرافدين / ج / / مجلة V / Y Y T

\section{1. (IM. 235570)}

Obv.
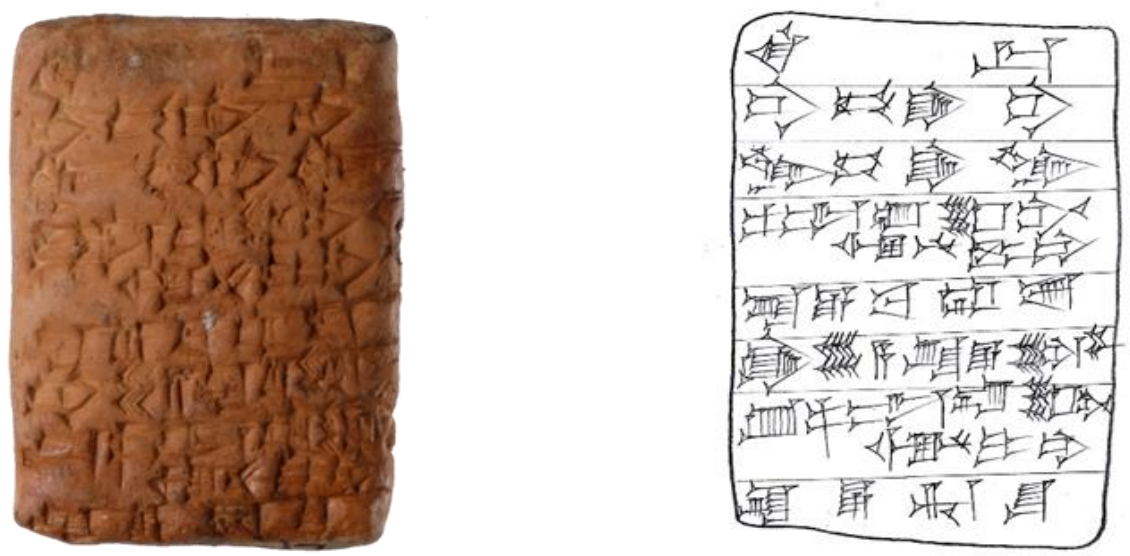

Rev.
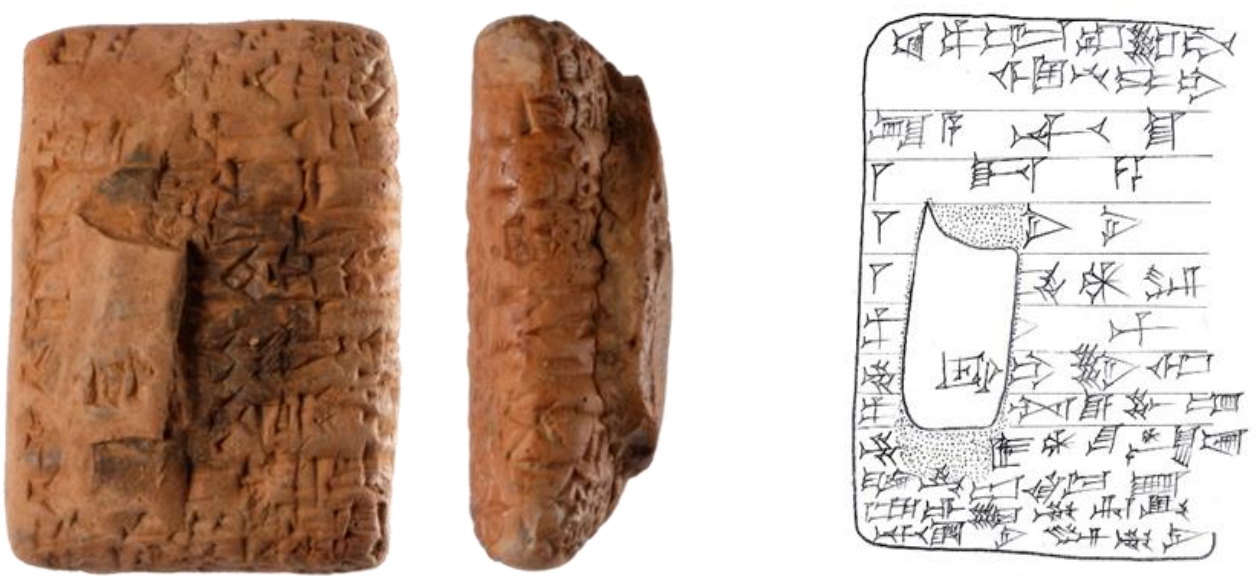

0

$5 \mathrm{~cm}$ 
علي محمد احمد

نصان مسماريان جديدان من مدينة أيري - ساكرك يتضمنان صيغاً أكدية

خالد سالم أسماعيل

Cub (puppy) small

I didn't cut

Sour milk (to) grows

Rev.

The bull of the Palace is in the basket (cage)

don't die

I swear in the name of the king

( Inspector) (administrative) [.......]

The year (in which) Shu-Sin, king of Ur, built the great obelisk of the $\operatorname{god}$

Enlil and the goddess Ninlil.

\section{The general content:}

A text includes an oath in the name of the king who said shepherds swear not to cut fodder and sour milk from the young bull and young cub.

According to SBAH decision No. 161 in 2017 which came to the Iraq Museum by the cooperation of the Iraqi Ministry of Foreign Affairs and the Iraqi Ministry of Culture. 


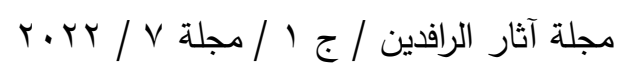

\section{2. (IM.235558):}

\section{Obv.}

1. diš ba-ba-e

diš i-tur 2 -DIĞIR

diš a-la-li

gud $e_{2}$-gal la e-re?-šu

5. amar-ga

amar-kir ${ }_{4}$ ?

la a-ap-ra-su

ga-š[e-a l]a e-le-pu

Rev.

gud e $e_{2}$-gal i-na/ na-ašs-bi-im

10. la e-mu-tu

mu lugal-bi in- $\left[\mathrm{pad}_{3}\right]$

šabra $[\ldots . . . .$.

$\mathrm{mu}^{\mathrm{d} \cdot \mathrm{s}}\left[\mathrm{u}-{ }^{\mathrm{d}}\right.$ EN.ZU lugal $]$ uri ${ }_{5}^{[\mathrm{ki}]}-\left[\mathrm{ma}-\mathrm{ke}_{4}\right.$

na-ru ${ }_{2}$-a]/ mah [ ${ }^{\mathrm{d}}$ en-lil ${ }_{2}{ }^{\mathrm{d}}$.nin-lil ${ }_{2}-\mathrm{ra} /$

mu-ne-du $\left.{ }_{3}\right]$

\section{Translation:}

Babae

E-Tur-ili

a-nu-li

The bull of the palace is not (used) for plowing

Small Bull 
علي محمد احمد

نصان مسماريان جديدان من مدينة أيري - ساكرك يتضمنان صيغاً أكدية

خالد سالم أسماعيل

The unplowed field of the clerk inspector in charge of ten oxen and supervisor of plowing oxen

Unplowed

Unplowed land for the inspector, the clerk in charge of ten oxen and the supervisor of the plowing oxen

do not graze

10 da-za

i-tur-ili

turām-iškur

bull shepherds

Swear in the name of the king

Inspector urdu-e-bu-um

The year after (the year in which) Šu-Suen, king of the city of Ur

He built a wall of Martu (Ammuru) Murīq-tidnim

\section{The general content:}

A text that includes an oath in the name of the king by herdsmen of bulls and donkeys swear not to cut off fodder and milk from young bulls and donkey. 


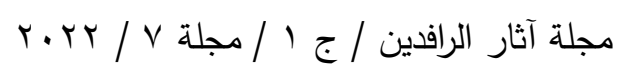

ga-še-a la e-le-pu

$\operatorname{gan}_{2}$ šabra dub-sar gud $10 / \mathrm{u}_{3}$ nu-banda 3 gud

la e-re-šu

Rev.

$\mathrm{su}_{7}$ šabra dub-sar gud $10 \mathrm{u}_{3} /$ nu-banda 3 gud

10. la a-di $\mathrm{i}_{3}-\mathrm{es}_{2}$

diš da-za

diš $[i-t u] r_{2}-i_{3}-1 i_{2}$

diš t[u-ra-]am- ${ }^{d}$ iškur

sipa gud-meš

15. mu [lugal]-bi in-pad ${ }_{3}$-ne-ešs

šab[ra] urdu ${ }_{2}$-e-bu-um

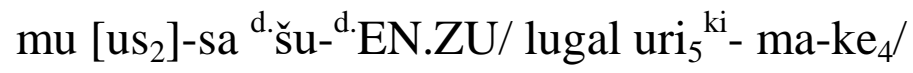

bad $_{3}$ mar-tu mu-ri-iq/ ti-id-ni-im

mu-du 3

\section{Translation:}

As for

Your little bulls

your little donkeys

Inspector clerk in charge of ten oxen and supervisor of plowing oxen .

I didn't cut

Sour milk (in order) to grow 
نصان مسماريان جديدان من مدينة أيري - ساكرك يتضمنان صيغاً أكدية لي محم احمد خالد سالم أسماعيل

Whereas we find the only verb he mentioned in Sumerian form in the two texts is the verb of the oath. in- $\operatorname{pad}_{3}$-ne-eš meaning swear ${ }^{(10)}$ : in-pad 3 -ne-ěs

while we find the same verb in other corresponding documents published by researcher David Owen, where they came in Akkadian formulas as follows:

$$
\text { ni-iš lugal it-ma }{ }^{(11)}
$$

These two texts also contained many personal names of Akkadian origins in Ur III period, especially during the reign of Kings Šu-Suen and Ibi-Suen:

$$
\begin{aligned}
& \text { i-tur } 2-\mathrm{i}_{3}-\mathrm{li}_{2} \\
& \text { tu-ra-am- }{ }^{\mathrm{d}} \text { Iškur }{ }^{(12)}
\end{aligned}
$$

whereas we found two new rare names which we also think that they are of Akkadian origins:

ba-ba-e?

a-la-li?

Below is the transliteration of the two texts, their translation, and analysis of some of the formulas and notes:

\section{1. (IM.235570):}

Obv.

1. ki-ma gud amar-ga gud anše amar-ga anše šabra dub-sar gud $10 / \mathrm{u}_{3}$ nu-banda 3 gud

5. la e-pa 2 -ra-su 


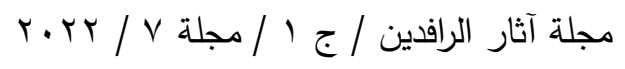

us a clear understanding of the wide use of Sumerian formulas in economic documents of the Early Old Babylonian period or the later one. That is considered as a natural development for the emergence of bilingual texts. One of the observations that we can make on these two texts is the absence of the name of the month before the historical formula, which, as we have mentioned before, it goes back to the age of Šu-Suen (2037-2029 BC). This matter is applicable to the text numbered (IM. 235545) from the reign of King Ibi-Suen. It is of great importance here to mention some details about these two texts in the following table:

\begin{tabular}{|c|c|c|c|c|}
\hline No. & IM. & Size in $\mathrm{cm}$ & Object & Date \\
\hline 1. & 235570 & $6.4 \times 4.5 \times 1.7$ & Oath of herdsmen & ŠS 05 \\
\hline 2. & 235558 & $5.8 \times 4.9 \times 2$ & Oath of herdsmen & ŠS 06 \\
\hline
\end{tabular}

\section{The Akkadian formulas mentioned in the two texts:}

Some of the Akkadian formulas in these two texts are not from the common formulas in the Akkadian language. And their meanings are not clear, as it has been pointed out by the fact that Sigarist in his new book CUSAS, 40/1;2 has left it without clear translation or clear analysis ${ }^{(7)}$, his explanation of the archive did not contain photos and copies of the cuneiform texts in order to verify the reading or translation. It seems that the writer of the text used the infinitive (e-re-šu) $)^{(8)}$, which means "plow?", as well as the nominative form na-aš-pi-im ${ }^{(9)}$. Apart from this, the other Akkadian verbal formulas are simple verbal ones: (e-mu-tu,a-di ${ }_{3}$-ešs,, e-pa 2 -ra-su). 


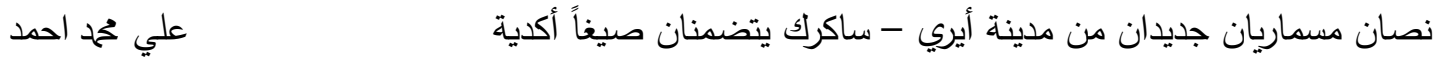 خالد سالم أسماعيل}

It is, of course, included in the so-called archive of the city of Iri-Sağrig, by (Sigarist, M.; Ozaki, T.), who published it in a new volume, CUSAS, 40/1;2 (2) as well as an article written by David Owen within the researches of the Paris Conference on Assyriology in 2019, which was titled "Akkadian Field Cultivation and Other Akkadian Contracts from Iri-Sağrig" (3).

In fact, we have already dealt with an Akkadian text from the Sumerian Ur III period that deals with the same ideas, but it dates back to the second year of the reign of King Ibi-Suen ${ }^{(4)}$.

It is useful to say that most of the cuneiform texts that we have received so far from the Ur III periods contain Akkadian formulas and contents whose date goes back to the reign of King Šu-Suen, with the exception of the text marked (IM. 235545). These texts are classified as a grazing contract dating back to the second year of the reign of King Ibi-Suen ${ }^{(5)}$. The purpose of our focus on talking about the reigns of kings contained the Akkadian formulas for contracts and economic documents also include many Semitic names, is to determine when these formulas began to be used and why? Does this matter indicate a state of the effect of community coexistence between the Semitic Akkadians and the Sumerians during the reign of the last two kings of Ur III period (we mean Šu-Suen and Ibi-Suen)? Or that it came as a result of the influence of the Western Semitic (Amorite) penetration, which began to clearly dominate all aspects of daily life, especially in the last years of the reign of King Ibi-Suen (2028-2002) B.C ${ }^{(6)}$. Regardless of the details included in this type of economic documents, they certainly make us feel clearly the great influence on the political life at the end of the Ur III period. As we have emphasized in a previous article the presence of new evidences and proofs of the use of Akkadian formulas in the Sumerian texts. This gives 


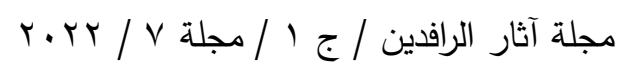
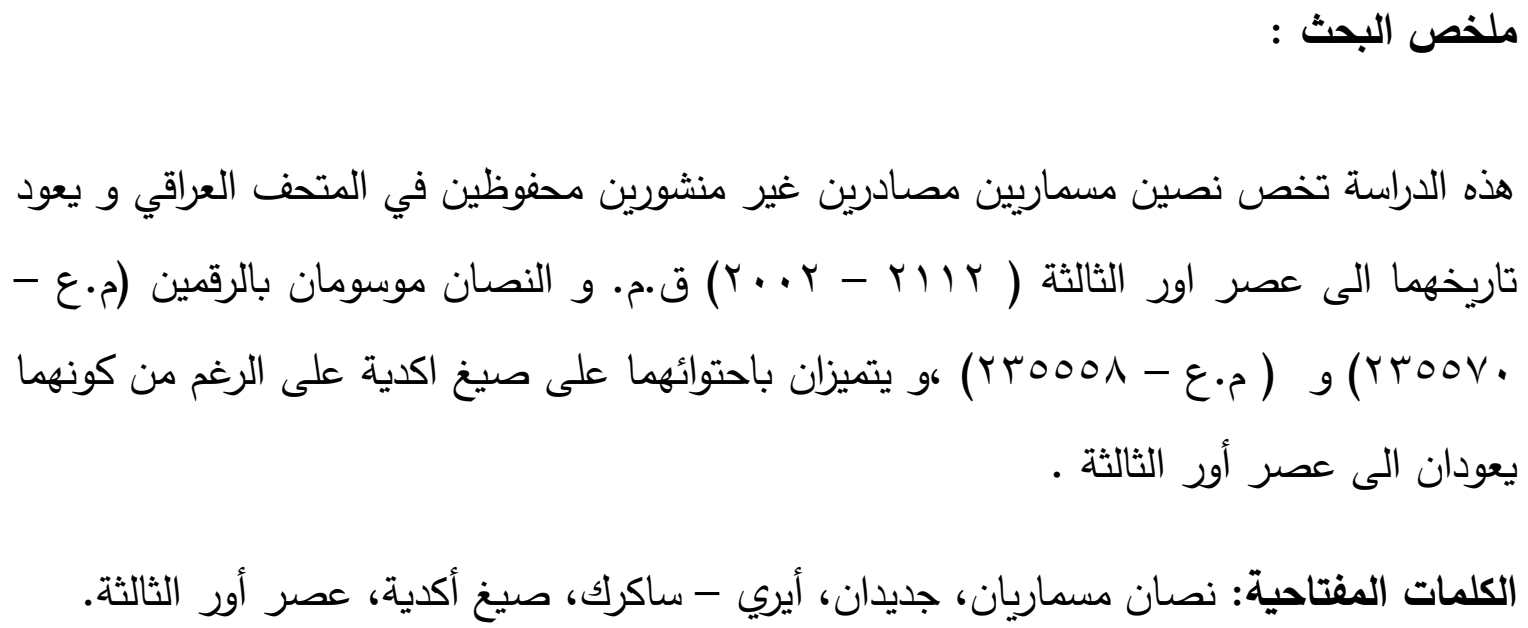

\section{Introduction:}

There are collections of the confiscated cuneiform tablets came to the Iraq Museum in 2017.They are about (1000) pieces, consisting of (300) artifacts and (700) cuneiform tablets, most of them are dated to Ur III period (2112 2002) B.C. Through studying many of them especially the texts we have which start with (IM. 235000) and end with (IM. 235999), we believe they belong to Iri-Sağrig based on the names of the months which are identical to the calendar of Iri-Sağrig.

The date of the two cuneiform texts which we will tackle in this article goes back to the fifth and sixth years of the reign of King Šu-Suen (20372029) BC. He is the fourth king of Ur III, whose reign was famous for the abundance of the texts and the economic documents. The importance of these two texts lies in the fact that they contain Akkadian formulas in two unique Sumerian texts dating to Ur III period $^{(1)}$. In fact, we are now familiar with this matter in many modern researches, it seems to us that a good collection of cuneiform texts that were published dated back to Ur III period. 


\title{
Two New Cuneiform Texts from Iri-Sağrig Including Akkadian Formulas
}

\author{
Ali Mohammed Ahmed \\ Master Student \\ alialhashmiy@yahoo.com
}

\author{
Khalid Salim Ismael \\ University of Mosul- College of Archaeology \\ kh_salim65@yahoo.com
}

\begin{abstract}
:
This study concerns two unpublished confiscated cuneiform texts kept in the Iraq Museum belong to Ur III period (2112 - 2002) B.C.E. (IM. 235570); (IM.235558 ). Although, the texts belong to Ur III period, they contain Akkadian formulas. The subject of these texts is an oath in the name of the king by herdsmen of bulls and donkeys.
\end{abstract}

Keywords: Two, New, Cuneiform, Texts, Iri-Sağrig, Akkadian, Formulas.

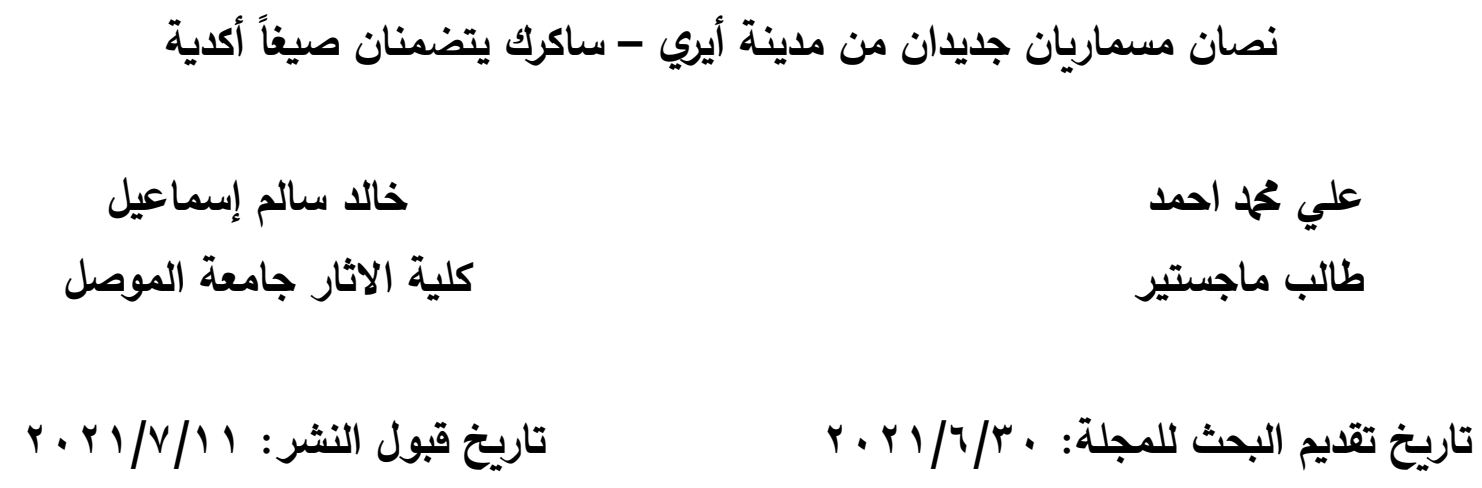





\section{Contents}

\begin{tabular}{|c|c|c|}
\hline Page & Research Name & Subject \\
\hline 1 & Khalid Salim Ismael & Preface \\
\hline $3-23$ & Wathiq Al-Salihi & Palm Trees In the Greco-Roman World \\
\hline $25-56$ & $\begin{array}{l}\text { Ansam Zuhair Khudur } \\
\text { Jaber Khaleel Ibrahim }\end{array}$ & $\begin{array}{c}\text { The Route of Alexander the Great to } \\
\text { Gaugamela }\end{array}$ \\
\hline $57-78$ & Hussein Dhahir Hammood & $\begin{array}{l}\text { Study in the Bronze Head of the } \\
\text { Akkadian Revealed }\end{array}$ \\
\hline $79-95$ & $\begin{array}{c}\text { Narmin Ali Muhammad Amen } \\
\text { Miroslav Melčák } \\
\text { Karel Nováček } \\
\end{array}$ & $\begin{array}{c}\text { Development of Altyn Köprü (Pirdi) in } \\
\text { the Light of New Archaeological and } \\
\text { Historical Research }\end{array}$ \\
\hline $97-129$ & $\begin{array}{c}\text { Abbas Abed Mandeel } \\
\text { Torhan Modher Al-Mufti }\end{array}$ & $\begin{array}{l}\text { Tattoos are a Manifestation of the } \\
\text { Ancient Mesopotamian Heritage }\end{array}$ \\
\hline $131-164$ & Mazin Zara & $\begin{array}{l}\text { Mesopotamian Dome - Bakhdeda } \\
\text { Dome as a Model }\end{array}$ \\
\hline $165-184$ & Luay Kadhim Sae’a & $\begin{array}{l}\text { Unpublished Economic Akkadian } \\
\text { Texts In The Iraq Museum }\end{array}$ \\
\hline $185-204$ & $\begin{array}{l}\text { Hashim Taha Raheem Alzubeedy } \\
\text { Nihad Hasan Haji Alshammary }\end{array}$ & $\begin{array}{c}\text { The Singer's Manuscript in } \\
\text { Abbreviating Al-Tawtea's Book a } \\
\text { Grammar of the Samaritan Language }\end{array}$ \\
\hline $205-238$ & $\begin{array}{l}\text { Munther Abdul-Moneim } \\
\text { Muhammad Yunus Al-Taie }\end{array}$ & $\begin{array}{c}\text { Handicraft Decorations (Arabesque)- } \\
\text { Past, Present and Future - Syria as a } \\
\text { Model }\end{array}$ \\
\hline \multicolumn{3}{|c|}{ English Part: } \\
\hline $3-15$ & $\begin{array}{l}\text { Ali Mohammed Ahmed } \\
\text { Khalid Salim Ismael }\end{array}$ & $\begin{array}{l}\text { Two New Cuneiform Texts from Iri- } \\
\text { Sağrig Including Akkadian Formulas }\end{array}$ \\
\hline
\end{tabular}


12- The original research papers submitted to the magazine are not returned to their owners, whether published or not.

13- Tables and figures are numbered in a row according to their appearance in the research, provided with titles, submitted with separate papers, blueprints are submitted in black ink and images to be in high resolution.

14- The marginal numbers are written in parentheses and are presented in series at the end of the research.

15-The full source name is indicated in the margin, with the abbreviated source in parentheses at the end of the margin.

16- The researcher is responsible for correcting the linguistic and typographical errors in his research.

17- The magazine operates according to self-funding. Therefore, the researcher bears the publication fees of $(100,000)$ one hundred thousand Iraqi dinars.

18- Each researcher shall be provided with one copy of his research. As for the full copy of the journal, it is requested from the magazine's secretariat and a price is determined by the Editorial Board.

19- The papers should be sent to the journal e-mail: 


\section{Publishing rules in Athar Al-Rafedain Journal (AARJ):}

1- The journal accepts scientific research that falls in specializations:

- Ancient Archaeology and Islamic Archaeology .

- Ancient languages with their dialects and comparative studies.

- Cuneiform Inscriptions and ancient lines.

- Historical and cultural studies

- Archaeological geology.

- Archaeological survey techniques.

- Anthropological studies.

- Conservation and restoration.

2- Research papers shall be submitted to the magazine in both Arabic and English.

3- The research shall be printed on (A4) paper, word-2010 system, with double spaces between lines, Simplified Arabic font for Arabic language, Times New Roman for English language, delivered on $\mathrm{CD}$, and in two paper based copies.

4- The title of the research should be printed in the middle of the page, followed by the name of the researcher, his academic degree, his full work address, and e-mail.

5- The research should contain an abstract in Arabic and English languages, it shouldn't exceed (100) words.

6- The abstract of the research in English contains the title of the research, the name of the researcher, his academic degree, his full workplace, and his e-mail.

7- The research must include keywords related to the title of the research and its content.

8- That the research was not previously published or was submitted to obtain a degree or is derived from the intellectual property of another researcher, and the researcher must undertake this in writing when submitting it for publication.

9- The researcher is obliged to follow the correct scientific foundations in his research.

10- The researcher is obligated to amend his research terms to suit the experts 'suggestions and the method of publishing in the journal.

11- The number of research pages does not exceed (25) pages, and in case of exceeding the required number, the researcher shall pay an additional amount for each additional page. 
Arabic Language Expert

Dr. Maan Yahya Mohammed

Dep. Of Arabic Language /College of Arts / University of Mosul

English Language Expert

Assist. Lect. Ammar Ahmed Mahmood

Dep. Of Translation Language / College of Arts / University of Mosul

Design and Format

Assist. Lect. Thaer Sultan Darweesh

Assist. Lect. Oday Abdulwaheb Abdullah

\author{
Design Cover \\ Dr. Amer Al-Jumaili
}




\section{$\underline{\text { Editorial Board }}$}

\section{Prof. Khalid Salim Ismael \\ Editor-in-Chief}

\section{Assist Prof. Hassanein Haydar Abdlwahed \\ Managing Editor}

\section{Members}

Prof. Elizabeth Stone

Prof. Adeileid Otto

Prof. Walther Sallaberger

Prof. Nicolo Marchetti

Prof. Hudeeb Hayawi Abdulkareem

Prof. Jawad Matar Almosawi

Prof. Rafah Jasim Hammadi

Prof. Abel Hashim Ali

Assist Prof. Yasamin Abdulkareem Mohammed Ali

Assist Prof. Vyan Muafak Rasheed

Assist Prof. Hani Abdulghani Abdullah 



\section{Journal}

\section{Athar Al-Rafedain}

Accredited Scientific Journal

It Search's in Archaeology of Iraq and Ancient Near East

Published by College of Archaeology - University of Mosul

E-Mail: $\underline{\text { uom.atharalrafedain@gmail.com }}$

Vol.7 / No.1

Jamadi al-awal. 1443 A.H. / January. 2022 A.D. 

University of Mosul
College of Archaeology

is

4

$\overline{3}$

.3

ㄱ.

$>$

กิ

e

$\frac{1}{9}$

(5)

$+$

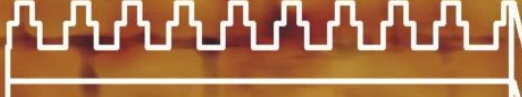
$0,0 \quad 0$ 乃约

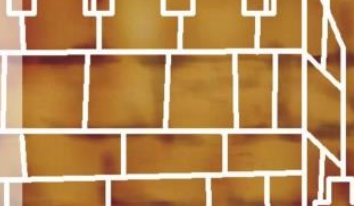

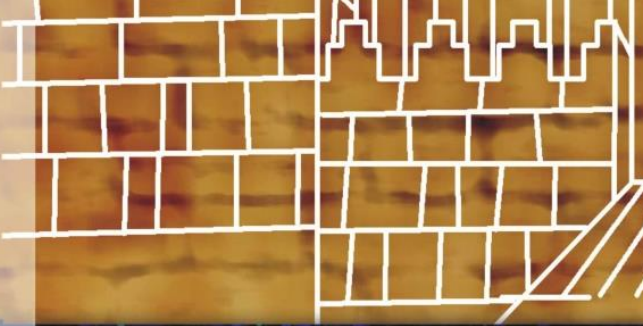

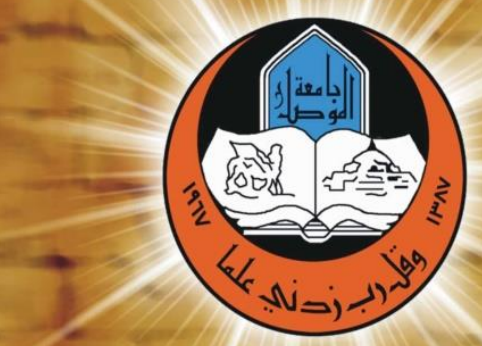

(
Ministry of Higher

Education and Scientific

Research

ISSN 2304 - 103X(Print)

ISSN 2664-2794(Online)

$\| r=\square]$

Academic Scientific Journals

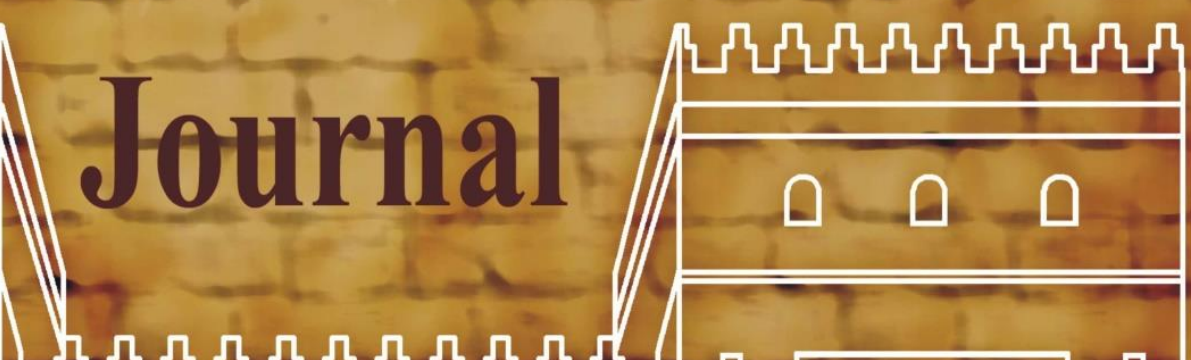

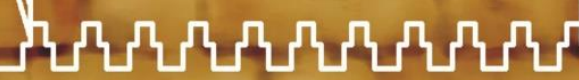
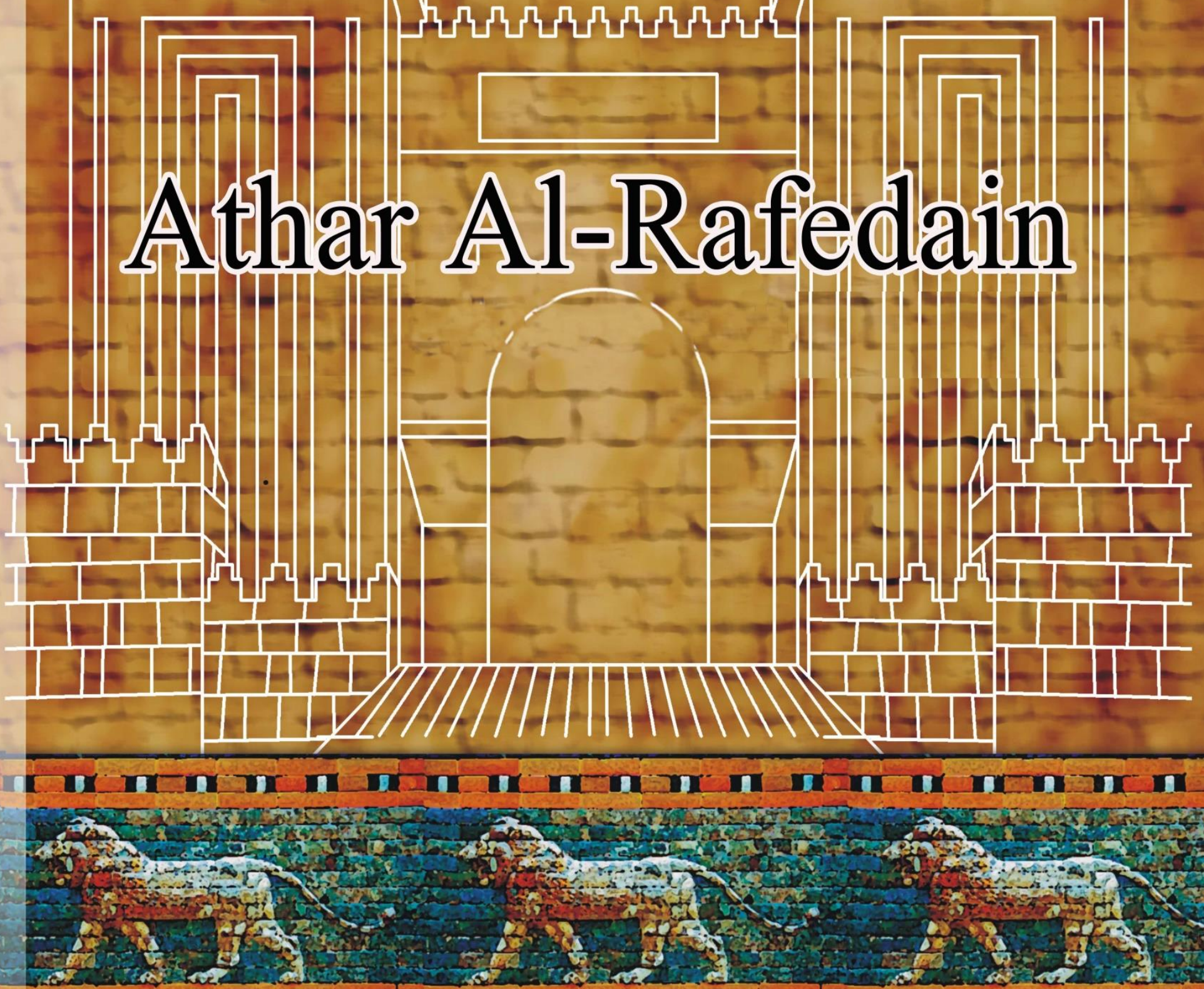

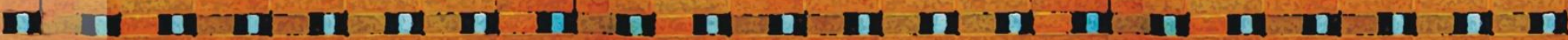

Accredited Scientific Journal It Search's in Archaeology of Iraq and Ancient Near East

Published College of Archaeology - University of Mosul / Vol.7/ No.1 / 1443 A.H. / 2022 A.D. 